\title{
The ovarian secretion of androstenedione and oestradiol during late pregnancy and the early postpartum period in sheep with an autotransplanted ovary
}

\author{
RJ Scaramuzzi ${ }^{1 *}$, Y Cognié ${ }^{2}$, JA Downing 1 \\ 1 CSIRO Division of Animal Production, Locked Bag 1, Delivery Centre, Blacktown 2148, \\ NSW, Australia; \\ 2 Station de physiologie de la reproduction, Centre de recherche, Inra de Tours, \\ 37380 Nouzilly, France
}

(Received 2 April 1996; accepted 26 July 1996)

\begin{abstract}
Summary - During late pregnancy in the ewe, ovarian function is suppressed by placental steroids and following parturition ovarian function is restored. This experiment determined the ovarian secretion of oestradiol and androstenedione during late pregnancy and the early postpartum period in ewes. Six ewes with ovarian autotransplants were transplanted with three day 6 embryos and three gave birth on day 147. Ovarian and jugular blood sampled were collected on three different occasions. On each occasion a $4 \mathrm{~h}$ period of sampling was followed by a 6 or $8 \mathrm{~h}$ period during which the ewes were challenged with $150 \mathrm{ng}$ of gonadotropin-releasing hormone (GnRH). Basal secretion of oestradiol and androstenedione was $0.3 \pm 0.1$ and $10.5 \pm 3.0 \mathrm{ng} \mathrm{min}^{-1}$, respectively, on day 120 of pregnancy.

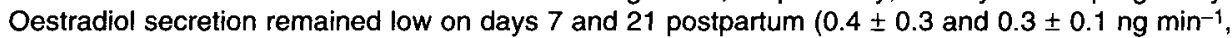
respectively). Androstenedione secretion ( $\mathrm{ng} \mathrm{min}^{-1}$ ) on days 7 and 21 postpartum was $2.5 \pm 0.5$ and $4.1 \pm 1.8$, respectively. The injection of $\mathrm{GnRH}$ on day 121 of pregnancy produced luteinizing hormone (LH) release with a peak concentration of $0.6 \pm 0.1 \mathrm{ng} \mathrm{mL}^{-1}$, that did not stimulate steroid secretion. On day 8 postpartum $\mathrm{GnRH}$ injection induced $\mathrm{LH}$ release with a peak concentration of $3.9 \pm 1.1 \mathrm{ng} \mathrm{mL}-1$ that stimulated secretion of oestradiol $\left(0.2 \pm 0.1\right.$ to $\left.2.1 \pm 0.9 \mathrm{ng} \mathrm{min}^{-1} ; P<0.01\right)$ and androstenedione ( $2.3 \pm 0.6$ to $17.1 \pm 6.9 \mathrm{ng} \mathrm{min}^{-1} ; P<0.001$ ). Similar effects were seen on day 22 postpartum; $\mathrm{GnRH}$ injection induced $\mathrm{LH}$ release with a peak concentration of $4.7 \pm 1.4 \mathrm{ng} \mathrm{mL}^{-1}$ that stimulated secretion of oestradiol $\left(0.2 \pm 0.1\right.$ to $\left.3.7 \pm 1.1 \mathrm{ng} \mathrm{min}^{-1} ; P<0.001\right)$ and androstenedione $(4.2 \pm 2.6$ to $29.5 \pm 9.2$

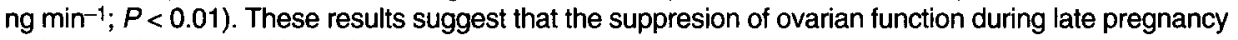
in the ewe is reversed by 7 days postpartum.
\end{abstract}

\section{oestradiol / androstenedione / LH / pregnancy / ovary}

* Present address: Department of Veterinary Basic Sciences, Royal Veterinary College, University of London, Royal College Street, London NW1 OTU, UK 
Résumé - Chez la brebis pendant la gestation, la fonction ovarienne est inhibée par les stéroïdes placentaires. Après la mise bas, la fonction ovarienne est rétablie. L'expérience suivante a permis de déterminer les sécrétions ovariennes d'cestradiol et d'androstènedione chez la brebis en gestation et post-partum. Six brebis aux ovaires autotransplantés ont été implantées chacune avec trois embryons 6 jours après la fécondation et trois d'entre elles ont mis bas à j147. Des échantillons de sang ovarien et de sang prélevé à la veine jugulaire ont été collectés à trois moments. $\dot{A}$ chaque fois, une période de prélèvement de quatre heures a été suivie d'une période de six ou huit heures durant laquelle elles ont été soumises à une stimulation par $150 \mathrm{ng}$ de GnRH. Les sécrétions basales d'œestradiol et d'androstènedione ont été respectivement de $0,3 \pm 0,1$ et de $10,5 \pm 3,0 \mathrm{ng} \mathrm{min}^{-1}$ à j120 de gestation. La sécrétion d'œestradiol est restée faible aux jours 7 et 21 (respectivement $0,4 \pm 0,3$ et 0,3



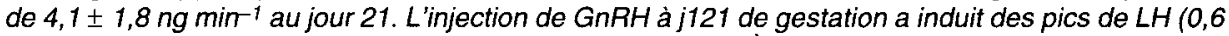

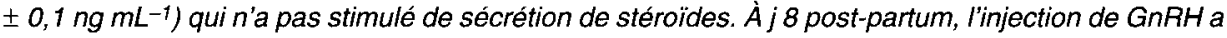

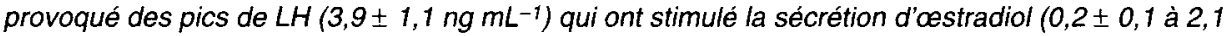
$\left.\pm 0,9 \mathrm{ng} \mathrm{min}^{-1} ; \mathrm{P}<0,01\right)$ et d'androsténedione $\left(2,3 \pm 0,6\right.$ à 17,1 $\left.\pm 6,9 \mathrm{ng} \mathrm{mim}^{-1} ; \mathrm{p}<0,001\right)$. Des effets similaires ont été observés à 22 post-partum ; l'injection de GnRH a provoqué des pics de $\mathrm{LH}(4,7 \pm$ $\left.1,4 \mathrm{ng} \mathrm{mL}^{-1}\right)$ qui ont stimulé la sécrétion d'œestradiol $\left(0,2 \pm 0,1\right.$ à $\left.3,7 \pm 1,1 \mathrm{ng} \mathrm{min}^{-1} ; \mathrm{p}<0,01\right)$ et d'androsténedione $\left(4,2 \pm 2,6\right.$ à $\left.29,4 \pm 9,2 \mathrm{ng} \mathrm{min}^{-1} ; \mathrm{p}<0,001\right)$. Ces résultats suggèrent que l'inhibition de la fonction ovarienne pendant la gestation est supprimée dès j7 post-partum.

cestradiol / androsténedione / LH / gestation / ovaire

\section{INTRODUCTION}

There is a paucity of information concerning follicular development and function during pregnancy of the sheep. During late pregnancy (day 140) in the ewe virtually all follicles of $1 \mathrm{~mm}$ or greater are atretic (AlGubory and Martinet, 1986). Other data from cattle and pigs (Rexroad and Casida, 1975) suggest that although some follicular development occurs early in pregnancy, by the final third of pregnancy the ovaries are almost totally devoid of large antral follicles. The same appears to be true for humans (Govan, 1968, 1970) but not for rodents (Greenwald, 1966, 1967; Greenwald and Choudary, 1969; Pedersen and Peters, 1971) or rabbits (Adams, 1968).

The functional state of these follicles has been difficult to assess in vivo because of the production of steroids by placental tissue and by the relative inaccessibility of the ovary with advancing pregnancy. Several in vitro studies with cultured ovarian follicular cells from pregnant rats (Richards and Kersey, 1979; Bogovich et al, 1981; Carson et al, 1981) suggest that follicular steroidogenesis is impaired in late pregnancy; in particular, there is a thecal deficiency of the $17 \alpha$-hydroxylase and C17-20 lyase enzymes (Bogovich and Richards, 1982). Following parturition follicular function is restored although the rate at which it is restored shows considerable intra- and interspecies variation. In some species a postpartum ovulation occurs normally, within 1 or 2 days of birth (rat; Connor and Davis, 1980) while in others the first postpartum ovulation can be normally delayed for several months (cow; Peters and Lamming, 1990; Short et al, 1990). In the ewe postpartum ovulation can occur within a week (Mauléon and Dauzier, 1965) or it can be delayed by several months depending on the time of the year (Abecia et al, 1992) and on nutrition (Shevah et al, 1975; Loudon, 1987). The time of the first postpartum ovulation can be delayed by lactation and the intensity of the suckling stimulus (Mauléon and Dauzier, 1965; Schirar et al, 1989).

The physiology of the ovary during the inactive state of late pregnancy and over the period of transition to an active state in the postpartum period is not clear. The low 
level of gonadotrophic support may be sufficient to explain ovarian inactivity in late pregnancy. Alternatively, the ovary may be inactive because of the direct effects of placental hormones on ovarian function.

Using the technique of superovulation and embryo transfer (Ward et al, 1986; Murray et al, 1989), pregnancies were established in three ewes with an ovarian autotransplant and ovarian function was studied prepartum and twice at postpartum. We are able to report the pattern of endogenous and gonadotropin-releasing hormone $(\mathrm{GnRH})$-induced secretion of follicular steroids from the ovary of the conscious pregnant ewe. A preliminary account of this experiment has been published as an abstract (Scaramuzzi et al, 1989).

\section{MATERIALS AND METHODS}

\section{Embryo transfer}

\section{Donor animals}

Twenty Border Leicester $X$ Merino cross ewes were used as donor animals.

\section{Recipient animals and diet}

Six Border Leicester $X$ Merino cross ewes with a mean body weight of $58.0 \pm 0.6 \mathrm{~kg}$ had the left ovary and vascular pedicle autotransplanted (Goding et al, 1967). The animals were studied in the normal breeding season and housed in a group pen with ad libitum access to a pelleted ration and water.

\section{Oestrous synchronization: embryo production and embryo transfer}

The procedure employed has been described elsewhere in detail (Ward et al, 1986; Murray et al, 1989). The embryo transfers were carried out in the nonbreeding (anoestrous) season so that the ewes would give birth and lactate during the nat- ural breeding season. Briefly, the oestrous cycles of both donor and recipient ewes were synchronized using progestagen (medroxy-progesterone actate) sponges (Repromap; Upjohn Pty Ltd, Rydalmere, NSW, Australia). Donor and recipient ewes were injected intramusculary with PMSG (Pregnecol; Intervet, Artarmon, NSW, Australia) $24 \mathrm{~h}$ before sponge removal. Donor ewes received $1000 \mathrm{IU}$ while recipient ewes received $750 \mathrm{IU}$. The donor ewes were inseminated with $100 \times 10^{6}$ sperm $24 \mathrm{~h}$ after sponge removal. The embryos were recovered from donor ewes at the early blastocyst stage 100 to $120 \mathrm{~h}$ postinsemination and assessed morphologically for normality (Ward et al, 1986; Murray et al, 1989). Three morphological normal blastocysts were transfered to each of six recipient ewes. The successful establishment of pregnancy was confirmed by ultrasound carried out 30 to 35 days post-transfer, in three of the six ewes.

\section{Experimental protocol}

From day 100 of pregnancy until 28 days after parturition the three pregnant ewes were bled three times a week by jugular venepuncture. On day 111 of pregnancy the ewes were placed in metabolism cages (Till and Downes, 1963) in a temperature controlled $\left(20^{\circ} \mathrm{C}\right)$ room and allowed to acclimatize for 1 week. While in the metabolism cages they were provided ad libitum with a pelleted ration and fresh water. The ewes were placed in a single metabolism cage and following parturition with a second cage placed alongside and the lower rails removed from both cages. This provided exclusive space for the lambs and allowed them to suckle the ewes during the experimental period, including the periods of intensive blood sampling.

\section{Experimental design}

Over the course of the experiment the ewes were subjected to three periods of intensive blood sampling: days 119 and 120 of pregnancy, days 7 and 8 postpartum and days 21 and 22 postpartum. On the first day of each period of intensive sampling the ewes were sampled at 15 min intervals for a total period of $6 \mathrm{~h}$. The next day the sampling was repeated for $5 \mathrm{~h}$ on day 120 of pregnancy and for $9 \mathrm{~h}$ on days 8 and 22 postpartum. On the second day of sampling each ewe 
was injected intravenously with $2 \mathrm{~mL}$ of saline containing $150 \mathrm{ng}$ of GnRH (Sigma Chemical Company, MO, USA) at $2 \mathrm{~h}$ (day 121 of pregnancy) and at 1 and $5 \mathrm{~h}$ (days 8 and 22 postpartum) of the intensive sampling period. Each sampling consisted of a timed ovarian venous blood $(5 \mathrm{~mL}$ ) followed immediately by a sample of jugular venous blood $(3 \mathrm{~mL})$. The blood was centrifuged at $4^{\circ} \mathrm{C}$, the plasma harvested and stored at $-20^{\circ} \mathrm{C}$.

\section{Cannulations}

On the day prior to the start of the intensive blood sampling all ewes had a polyvinyl cannula inserted into the jugular vein distal to the ovarian and jugular vein anastomosis, and a second polyvinyl cannula inserted into the contralateral jugular vein (Downing, 1994).

\section{Pharmaceutical treatments}

Following cannulation and daily thereafter, all ewes were given a $4 \mathrm{~mL}$ intramuscular injection of antibiotic (Hydropen; Bomac Laboratories, Castle Hill, NSW, Australia). Over the intensive blood sampling period all ewes were given a rapid intravenous injection of 5000 IU heparin (Boots Australia Pty Ltd, North Rocks, NSW, Australia) at the start of sampling and then every $3 \mathrm{~h}$. Between blood samples the cannulae were filled with heparinized saline $(50 \mathrm{IU} \mathrm{mL}-1)$.

\section{Hormone analysis}

The concentrations of luteinizing hormone (LH), progesterone (Downing et al, 1995), oestradiol and androstenedione (Dowing, 1994) were determined using established radioimmunoassays. Details of the antibodies and their specificities, the sensitivity and the inter- and intra-assay variability for these assays carried out in the same laboratory have been published in detail elsewhere (Downing, 1994; Downing et al, 1995).

\section{Progesterone}

The concentration of progesterone was determined in jugular venous blood collected three times weekly.

\section{Luteinizing hormone}

$\mathrm{LH}$ concentrations were determined in jugular venous plasma samples collected during the periods of intensive sampling.

\section{Oestradiol}

The concentration of oestradiol was determined in ovarian venous samples collected during the periods of intensive sampling. The time taken to collect each ovarian venous sample was recorded and the blood haematocrit determined hourly. These values were then used to determine the secretion rate of oestradiol (Collett et al, 1973).

\section{Androstenedione}

The concentration of androstenedione was determined in ovarian venous plasma collected during the periods of intensive sampling. The time taken to collect each ovarian venous sample was recorded and the blood haematocrit determined hourly. These values were then used to determine the secretion rate of androstenedione (Collett et al, 1973).

\section{Statistical analysis}

Differences in basal hormone concentrations and secretion rates were compared using a repeated measures analysis of variance (ANOVA, CRL; Clear Lake Inc, Houston, TX, USA). The maximum responses of $\mathrm{LH}$, oestradiol and androstenedione to $\mathrm{GnRH}$ injection were compared using Student's unpaired $t$-test.

\section{RESULTS}

\section{Embryo transfer}

Pregnancy was successfully established in three of the six recipient ewes with ovarian autotransplants. All three ewes carried to term and after an uneventful pregnancy delivered normally and unassisted on day 
147 of gestation. One ewe delivered a single lamb, one a set of twins and the third a set of triplets. Lactation was established and lambs suckled normally.

\section{Progesterone}

Progesterone concentrations were high over the last 40 days of pregnancy but fell rapidly at parturition (fig 1). Two ewes appeared to have ovulated within a few days of parturition and progesterone concentrations rose indicative of luteal activity (fig 1).

\section{Endogenous pulses of $\mathrm{LH}$}

No LH pulses were detected over the $6 \mathrm{~h}$ sampling period in any ewe on day 120 of pregnancy. On day 7 postpartum one ewe had a single LH pulse (amplitude $4.5 \mathrm{ng}$ $\mathrm{mL}^{-1}$ ); no $\mathrm{LH}$ puises were detected in the other two ewes. On day 21 postpartum one ewe (the same one) had a single LH pulse (amplitude $2.8 \mathrm{ng} \mathrm{mL}^{-1}$ ); no LH pulses were detected in the other two ewes. The mean concentrations of LH were low and not significantly different from each other at all three sampling periods (table I) and this is reflected in low endogenous secretion rates of oestradiol (table I). The secretion rate of androstenedione was elevated on day 120 of pregnancy when compared to the secretion rates on days 7 and 21 postpartum (table I); however, the differences were only significant on day 7 postpartum $(P=0.05)$.

\section{Responses to the GnRH challenge}

On day 121 of pregnancy the injection of $\mathrm{GnRH}$ induced significant LH release (fig 2) but, the maximum LH concentration was greatly reduced compared to the corresponding release induced by the same dose of $\mathrm{GnRH}$ on days $8(P<0.05)$ and $22(P<$ 0.05 ) postpartum (table II). There was no detectable increase in the secretion of either oestradiol or androstenedione around the time of the induced LH release (fig 2) although the basal secretion of androstenedione was elevated.

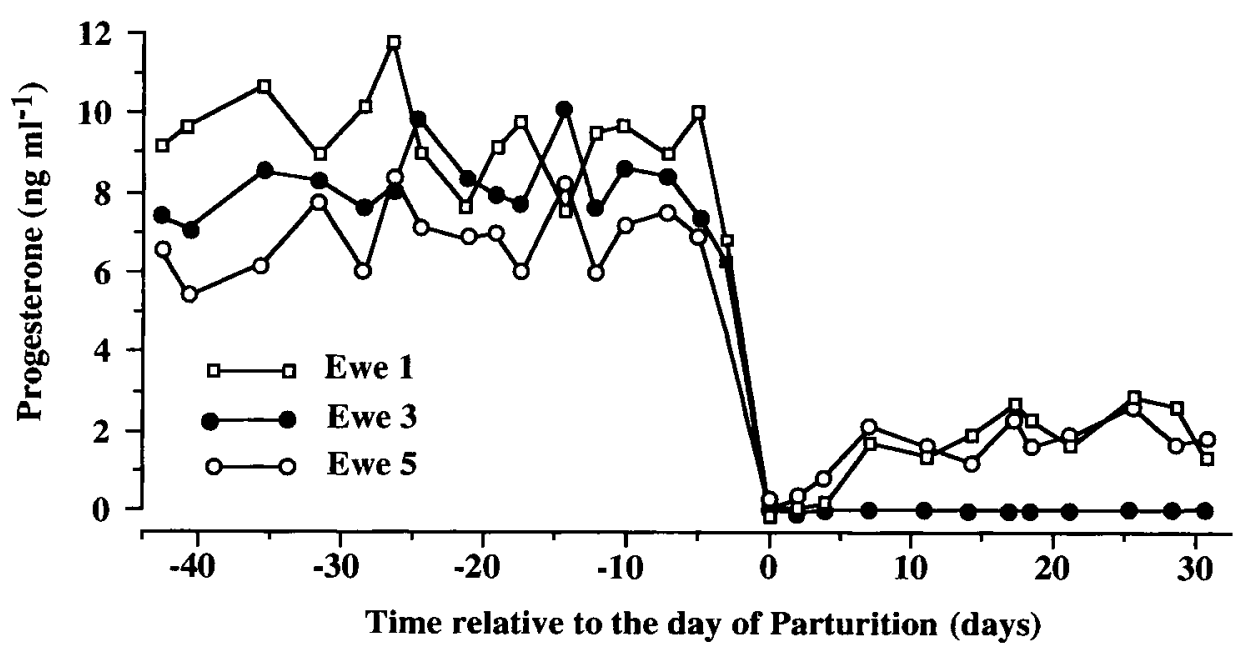

Fig 1. The plasma concentrations of progesterone in three ewes with an ovarian autotransplant from day 100 of pregnancy until day 28 postpartum. 




Fig 2. The mean $( \pm$ SEM) concentration of luteinizing hormone $(L H)$ and the mean ( \pm SEM) ovarian secretion rate of androstenedione and oestradiol in three ewes with an ovarian autotransplant on day 121 of pregnancy. The arrow indicates the time of a rapid intravenous injection of $2 \mathrm{~mL}$ of saline containing $150 \mathrm{ng}$ of gonadotropin-releasing hormone (GnRH). 
On day 8 postpartum both injections of $\mathrm{GnRH}$ induced significant $\mathrm{LH}$ release. There was no difference in the maximum $\mathrm{LH}$ concentration between the two injections (table II, fig 3). The secretion of both oestradiol $(P<0.001)$ and androstenedione $(P<$ 0.001 ) increased rapidly to a peak $75 \mathrm{~min}$ after $\mathrm{GnRH}$ and then declined significantly to basal secretion by $4 \mathrm{~h}$ after $\mathrm{GnRH}$. The second injection of $\mathrm{GnRH}$ also increased the secretion rates of oestradiol $(P<0.01)$ and androstenedione $(P<0.01)$ and maximum secretion was observed 60 and $45 \mathrm{~min}$ after GnRH (fig 3).

Table l. The mean ( \pm SEM) concentration of luteinizing hormone $(L H)$ and the mean ( \pm SEM) secretion rate of androstenedione and oestradiol in three ewes with an ovarian autotransplant on day 120 of pregnancy and on days 7 and 21 postpartum.

\section{Day 120 pregnant Day 7 postpartum Day 21 postpartum}

\begin{tabular}{lccc}
$\begin{array}{l}\mathrm{LH} \\
\left(\mathrm{ng} \mathrm{mL} \mathrm{m}^{-1}\right)\end{array}$ & $0.18 \pm 0.07$ & $0.42 \pm 0.23$ & $0.30 \pm 0.15$ \\
$\begin{array}{l}\text { Oestradiol } \\
\text { (ng min }\end{array}$ & $0.34 \pm 0.09$ & $0.33 \pm 0.27$ & $0.29 \pm 0.10$ \\
$\begin{array}{l}\text { Androstenedione } \\
\text { (ng min }\end{array}$ & $10.54 \pm 3.02 \mathrm{a}$ & $2.49 \pm 0.52 \mathrm{~b}$ & $4.11 \pm 1.77 \mathrm{ab}$ \\
\hline
\end{tabular}

ab Within rows values with the different superscripts differ at $P<0.05$.

Table II. The mean ( \pm SEM) maximum concentration of luteinizing hormone $(\mathrm{LH})$ and the mean $( \pm$ SEM) maximum secretion rates of oestradiol and androstenedione in three ewes with an autotransplanted ovary and challenged with a rapid intravenous injection of $150 \mathrm{ng}$ of gonadotropin-releasing hormone $(\mathrm{GnRH})$ on day 121 of pregnancy and on days 8 and 22 postpartum.

Day 121 pregnant

LH pulse height

(ng mL-1)

Maximum oestradiol

secretion rate $\left(\mathrm{ng} \mathrm{min} \mathrm{mi}^{-1}\right.$ )

Maximum androstenedione

secretion rate $\left(\mathrm{ng} \mathrm{min}^{-1}\right)$

$0.63 \pm 0.14 a$

$0.24 \pm 0.03^{a}$

$20.43 \pm 7.66$
Day 8 postpartum

Day 22 postpartum

$3.89 \pm 1.69 b$

$4.67 \pm 1.39 b$

$2.09 \pm 0.89^{b}$

$3.66 \pm 1.14 b$

$17.11 \pm 6.95$

$29.45 \pm 9.23$

The maximum secretion rates of oestradiol and androstenedione are the mean maximum secretion rate observed following $\mathrm{GnRH}$ and it occurred between 30 and $75 \mathrm{~min}$ after $\mathrm{GnRH}$ injection. ab Within rows values with different superscripts differ at $P<0.05$. 
On day 22 postpartum both injections induced significant $\mathrm{LH}$ release. There was no difference in the maximum $\mathrm{LH}$ concentration between the two injections (table II, fig 4). The secretion of both oestradiol $(P<$ $0.001)$ and androstenedione $(P<0.001)$ increased rapidly to a peak 75 and $60 \mathrm{~min}$ after GnRH and then declined to basal secretion by $4 \mathrm{~h}$ after $\mathrm{GnRH}$. The second injection of $\mathrm{GnRH}$ also increased the secretion rates of oestradiol $(P<0.001)$ and androstenedione $(P<0.01)$ and maximum secretion was observed $30 \mathrm{~min}$ after $\mathrm{GnRH}$ (fig 4).

\section{DISCUSSION}

This experiment reports the first account of the establishment of pregnancy in ewes with an autotransplanted ovary. Although only three of the six ewes became pregnant, the resulting data derived from these three animals is unique and offers further insights into the control of ovarian activity during the final trimester of pregnancy in the ewe. Clearly removal of the ovary and its relocation to a superficial site under the skin in the neck region (Goding et al, 1967) has not compromised the ability of the ovary to maintain pregnancy until such time as the developing placenta takes over this function. Parturition on day 147 of pregnancy was normal and progesterone concentrations fell sharply immediately prior to birth, confirming that luteolysis at the end of pregnancy does not require an intact utero-ovarian vasculature (Moor et al, 1970). Spontaneous luteolysis at the end of the oestrous cycle does not occur in nonpregnant ewes with an ovarian autotransplant and the cor- pora lutea persist beyond their normal life span of 14 days. The corpora lutea in ewes with an ovarian autotransplant regress spontaneously sometime between 100 and 150 days (Wheeler, 1973) and this is similar to the pattern of spontaneous regression of corpora lutea seen in the hysterectomized ewe (Moor et al, 1970). The corpora lutea of pregnancy appear to behave in a similar fashion because it is apparent that the corpora lutea had regressed before the time of the normal fall in placental progesterone that takes place just before parturition (Bassett et al, 1969).

There was a complete inhibition of $\mathrm{LH}$ pulse secretion on day 120 of pregnancy and this is consistent with other reports (AlGubory et al, 1989; 1994a) and is undoubtedly associated with the high rate of secretion of placental steroids, especially progesterone. Exogenous $\mathrm{GnRH}$ was able to induce pulses of $\mathrm{LH}$ on day 121 of pregnancy, but the amplitude of the resulting pulses was reduced. These data suggest that both the GnRH neuronal system and pituitary sensitivity of $\mathrm{GnRH}$ stimulation are strongly inhibited during pregnancy in the ewe. These inhibitory effects both appear to be rapidly reversed in ewes after parturition so that by day 7 postpartum, pulsatile $\mathrm{LH}$ secretion was restored and $\mathrm{LH}$ pulse amplitude was normal; this is consistent with other reports (Al-Gubory et al, 1989, 1994a). The influence of pregnancy on ovarian follicular development is not uniform across species and this presumably reflects species differences in placental function, particularly placental steroid secretion. Thus, in the rodent $\mathrm{LH}$ pulses are maintained and follicular development to the antral stage continues more or less throughout pregnancy (Greenwald and Roy, 1994). On the other

Fig 3. The mean ( \pm SEM) concentration of luteinizing hormone (LH) and the mean ( \pm SEM) ovarian secretion rate of androstenedione and oestradiol in three ewes with an ovarian autotransplant on day 8 postpartum. The arrows indicate the time of a rapid intravenous injection of $2 \mathrm{~mL}$ of saline containing $150 \mathrm{ng}$ of gonadotropin-releasing hormone $(\mathrm{GnRH})$. 
Day 8 Post-partum

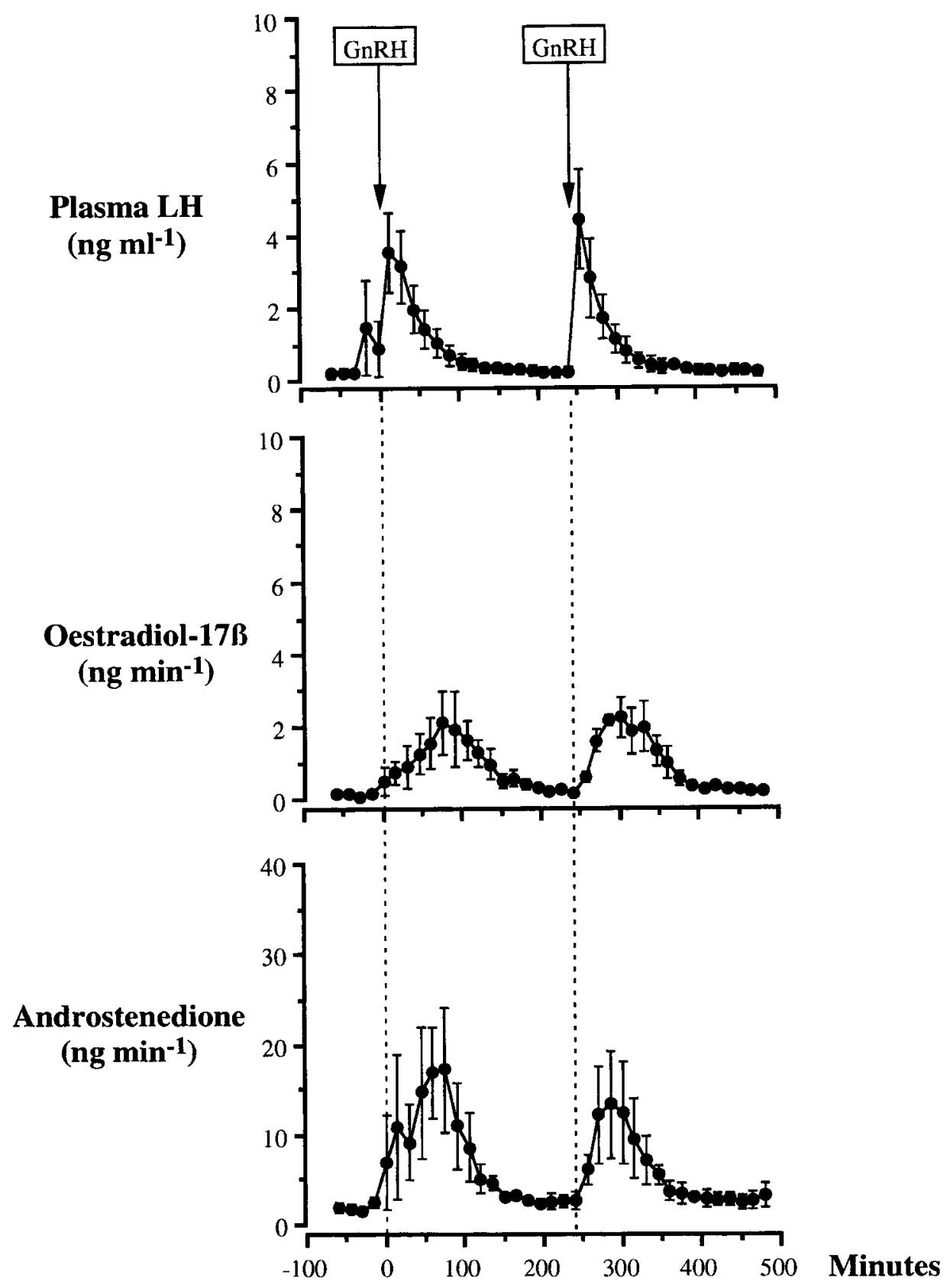




\section{Day 22 Post-partum}

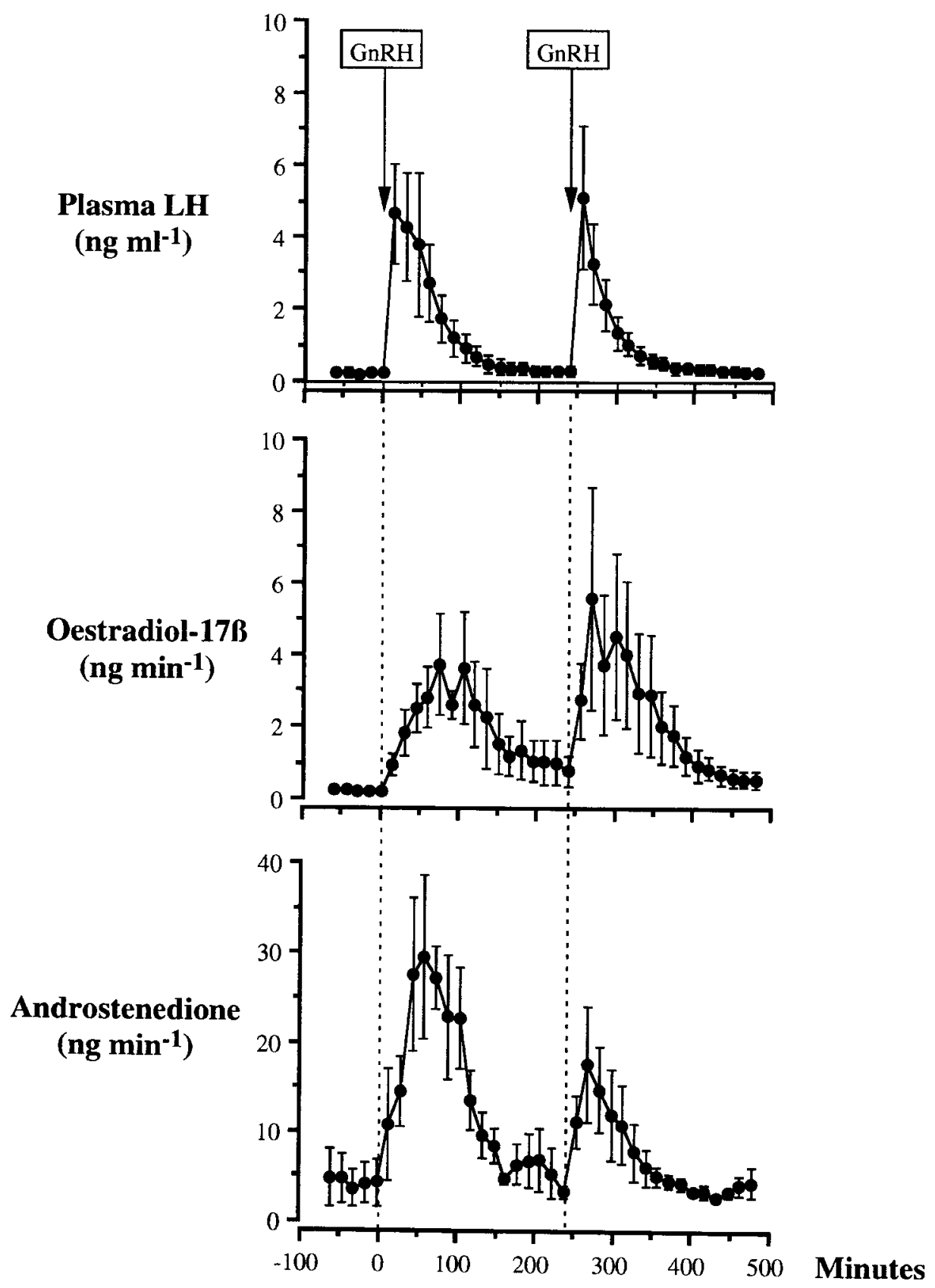


hand, pulsatile LH secretion is greatly inhibited during pregnancy in the sheep (AlGubory et al, 1989, 1994a) and the cow (Schallenberger et al, 1985) and the numbers of antral follicles are greatly reduced.

Some aspects of ovarian function were also suppressed in pregnancy. Basal secretion of oestradiol was low, suggesting an absence of large oestrogenic follicles at this stage of pregnancy and a low frequency of pulsatile LH release. Unlike the cow, the peripheral concentration of oestradiol in the pregnant ewe remains low until a day or so before parturition (Challis and Patrick, 1981). The secretion of androstenedione was markedly elevated on days 121 and 122 of pregnancy (table I, fig 2) and the peripheral concentration of androstenedione is elevated in maternal plasma during pregnancy in the ewe (Yu et al, 1983). These observations suggest that both the foetus and the ovary contribute to the elevated peripheral androgen concentrations seen in the pregnant ewe. The source of ovarian androstenedione is most likely small nonoestrogenic follicles (Al-Gubory and Martinet, 1986), although the pattern of secretion is atypical in that there appears to be a high rate of constitutive secretion (table I, fig 2). The high secretion of ovarian androstenedione leads to the novel suggestion that sheep ovary may be responding to placental hormones.

Since the amplitude of the GnRH-induced $\mathrm{LH}$ release was low in the pregnant ewes it is not possible to conclude definitively from these observations that ovarian responsiveness to $\mathrm{LH}$ is diminished during late pregnancy. There is little published information on the responsiveness of the ovine ovary to gonadotrophin stimulation during pregnancy and the question of ovarian responsiveness to gonadotrophins remains open.

Following parturition ovarian function was spontaneously and rapidly reestablished so that by day 7 two of the ewes had already ovulated before the first sampling period and before the first $\mathrm{GnRH}$ test on day 8. In all three ewes the ovarian responses to $\mathrm{GnRH}$-induced $\mathrm{LH}$ release were normal and the secretion of both oestradiol and androstenedione responded with a pulse of secretion similar to that observed in cycling ewes (Campbell et al, 1994). However, the frequency of spontaneous LH pulses was low suggesting that re-activation of the GnRH neuronal system from the inhibition of pregnancy is an important component of postpartum recovery (Jolly et al, 1995).

The present study clearly shows that the secretion rate of androstenedione was elevated on days 120 and 121 of pregnancy and that its basal secretion was greater than that observed on days 7 and 21 postpartum (table 1). Since androgens are normal precursors for oestrogen synthesis it appears that aromatization may be inhibited in late pregnancy. The inhibition of follicular oestradiol production during late pregnancy, even in the presence of high amounts of androstenedione, may result from low follicle-stimulating hormone (FSH) concentrations in the blood. After parturition the rapid increase in follicular growth (Al-Gubory and Martinet, 1986) coincides with increased secretion of FSH (Al-Gubory et al, 1989). Unfortunately, we did not measure jugular plasma concentrations of $\mathrm{FSH}$ in this experiment. There is also evidence that the corpus luteum (Al-Gubory et al, 1994b) and the placenta (Al-Gubory et al,

Fig 4. The mean ( \pm SEM) concentration of luteinizing hormone $(\mathrm{LH})$ and the mean ( \pm SEM) ovarian secretion rate of androstenedione and oestradiol in three ewes with an ovarian autotransplant on day 22 postpartum. The arrows indicate the time of a rapid intravenous injection of $2 \mathrm{~mL}$ of saline containing $150 \mathrm{ng}$ of gonadotropin-releasing hormone (GnRH). 
1995) contain nonsteroidal factors that inhibit granulosa cell aromatase activity.

\section{ACKNOWLEDGMENTS}

We wish to thank D Paliskis for expert technical assistance. Assistance with the embryo transfer procedures was provided by Dr CD Nancarrow and $\mathrm{Mr} \mathrm{J}$ Marshall. Antiserum to progesterone was supplied by Dr RM Hoskinson (CSIRO Division of Animal Production, Prospect, NSW, Australia). lodination grade ovine LH (G3-233) was supplied by Dr H Papkoff (University of San Francisco, San Francisco, CA, USA). The provision of reagents by the National Hormone and Pituitary Program for the assay of ovine LH assay is also gratefully acknowledged.

\section{REFERENCES}

Abecia JA, Forcada F, Zarazaga L (1992) Influence of nutrient status of postpartum Rasa Aragonesa ewes lambing in the seasonal anoestrus on the reactivation of oestrus activity and ovulation rate. In: Proceedings of the 12th International Congress on Animal Reproduction, The Hague, the Netherlands, 4, 20152017

Adams CE (1968) Ovarian response to human chorionic gonadotrophin and egg transport in the pregnant and post-parturient rabbit. J Endocrino/ 48, 101105

Al-Gubory KH, Martinet $J(1986)$ Comparison of the total ovarian follicular populations at day 140 of pregnancy and at day 5 postpartum in ewes. Theriogenology 25, 795-808

Al-Gubory KH, Blanc MR, Poirier JC, Solari A, Martinet $J(1989)$ Evidence that the corpus luteum of pregnancy contributes to the control of tonic secretion of $\mathrm{LH}$ in the ewe. J Reprod Fertil 85, 125-131

Al-Gubory KH, Blanc MR, Poirier JC (1994a) Effect of pregnancy and hysterectomy on pituitary gonadotrophin secretion in the ewe. Anim Reprod Sci 35, 209-222

Al-Gubory KH, Driancourt MA, Antoine M, Martal J, Neimer N (1994b) Evidence that a non-steroidal factor from corpus luteum of pregnant sheep inhibits aromatase activity of ovarian follicles in vitro. $J$ Reprod Fertil 100, 51-56

Al-Gubory KH, Machelon V, Nome F (1995) Evidence that a non steroidal factor from ovine placenta inhibits aromatase activity of granulosa cells in vitro. $C R$ Acad Sci (Paris) III, 318, 91-98
Bassett JM, Oxborrow TJ, Smith ID, Thorburn GD (1969) The concentration of progesterone in the peripheral plasma of the pregnant ewe. J Endocrinol 45, 449457

Bogovich K, Richards JS (1982) Androgen biosynthesis in developing ovarian follicles: evidence that luteinizing hormone regulates thecal $17 \alpha$-hydroxylase and C17-20-lyase activities. Endocrinology 111, 1201-1208

Bogovich K, Richards JS, Reichert LE Jr (1981) Obligatory role for luteinizing hormone $(\mathrm{LH})$ in the initiation of preovulatory follicular growth in the pregnant rat: specific effects of human chorionic gonadotropin and folicle-stimulating hormone on $\mathrm{LH}$ receptors and steroidogenesis in theca, granulosa and luteal cells. Endocrinology 109, 860-867

Campbell BK, Gordon BM, Scaramuzzi RJ (1994) The effect of ovarian arterial infusion of transforming growth factor $\alpha$ on ovarian follicle populations and ovarian hormone secretion in ewes with an autotransplanted ovary. J Endocrinol 143, 13-24

Carson RS, Richards JS, Kahn LE (1981) Functiona! and morphological differentiation of theca and granulosa cells during pregnancy in the rat: dependence on increased basal luteinizing hormone activity. Endocrinology 109, 1433-1441

Challis JRG, Patrick JE (1981) Sharp increase in free circulating oestrogen immediately before parturition in sheep. Can J Physiol Pharmacol 59, 970-978

Collett RA, Land RB, Baird DT (1973) The pattern of progesterone secretion by the autotransplanted ovary of the ewe in response to ovine luteinizing hormone. JEndocrinol 56, 403-411

Connor JR, Davis HN (1980) Postpartum estrus in Norway rats. I. Behaviour. Biol Reprod 23, 994-999

Downing JA (1994) Interactions of nutrition and ovulation rate in ewes. PhD thesis, Macquarie University, Sydney, NSW, Australia

Downing JA, Joss J, Connell P, Scaramuzzi RJ (1995) Ovulation rate and the concentrations of gonadotrophic and metabolic hormones in ewes fed lupin grain. J Reprod Fertil 103, 137-145

Goding JR, McCraken JA, Baird DT (1967) The study of ovarian function in the ewe by means of a vascular autotransplantation technique. J Endocrino/ 39, 3752

Govan ADT (1968) The human ovary in early pregnancy. $J$ Endocrinol 40, 421-428

Govan ADT (1970) Ovarian follicular activity in late pregnancy. $J$ Endocrinol 48, 235-241

Greenwald GS (1966) Ovarian follicular development and pituitary $\mathrm{FSH}$ and $\mathrm{LH}$ content in the pregnant rat. Endocrinology $79,572-578$

Greenwald GS (1967) Induction of ovulation in the pregnant hamster. Am J Anat 121, 249-258 
Greenwald GS, Choudary JB (1969) Follicular development and ovulation in the pregnant mouse. Endocrinology 84, 1512-1516

Greenwald GS, Roy SK (1994) Follicular selection and its control. In: The Physiology of Reproduction, 2d edn (E Knobil, J Neill, eds), Raven Press, New York, 629-724

Jolly PD, McDougall S, Fitzpatrick LA, Macmillian KL, Entwistle KE (1995) Physiological effects of undernutrition on postpartum anoestrus in cows. $J$ Reprod Fertil 49 (suppl), 477-492

Loudon ASI (1987) Nutritional effects on puberty and lactational infertility in mammals: some interspecies considerations. Proc Nutr Soc 46, 203-216

Mauléon $P$, Dauzier L (1965) Variations de durée de l'ancestrous de lactation chez des brebis de races llede-France. Ann Biol Anim Biochim Biophys 5, 131143

Moor RM, Hay MF, Short RV, Rowson LEA (1970) The corpus luteum of the sheep: effect of uterine removal during luteal regression. J Reprod Fertil 21, 319-326

Murray JD, Nancarrow CD, Marshall JT, Hazelton IG, Ward KA (1989) Production of transgenic Merino sheep by microinjection of ovine metallothioneinovine growth hormone fusion genes. Reprod Fertil Dev 1, 147-155

Pedersen T, Peters H (1971) Follicle growth and cell dynamics in the mouse ovary during pregnancy. Fertil Steril 22, 42-52

Peters AR, Lamming GE (1994) Lactational anoestrus in farm animals. Oxford Rev Reprod Biol 16, 245-288

Rexroad CE, Casida LE (1975) Ovarian follicular development in cows, sows and ewes in different stages of pregnancy as affected by number of corpora lutea in the same ovary. J Anim Sci 41, 1090-1097

Richards JS, Kersey KA (1979) Changes in theca and granulosa cell function in antral follicles during pregnancy in the rat: gonadotropin receptors, cyclic AMP and estradiol 17ß. Biol Reprod 21, 1185-1201
Scaramuzzi RJ, Cognié Y, Downing JA (1989) The secretion of oestradiol and androstenedione during late pregnancy and during the early post-partum period from the autotransplanted ovary of the ewe. Proc Endocrine Soc Austr 32, 165 (abstr)

Schallenberger E, Schondorfer AM, Walters DL (1985) Gonadotrophins and ovarian steroids in cattle. II. Pulsatile changes of concentration in the jugular vein throughout pregnancy. Acta Endocrinol (Copenh) $108,322-330$

Schirar A, Cognié $Y$, Louault F, Poulin N, Levasseur MC, Martinet J (1989) Resumption of oestrous behaviour and ovarian activity in suckling and nonsuckling ewes. J Reprod Fertil 87, 789-794

Shevah Y, Black WJM, Land RB (1975) The effects of nutrition on the reproductive performance of Finn $X$ Dorest ewes. II. Postpartum ovarian activity, conception and the plasma concentration of progesterone and LH. J Feprod Fertil 45, 289-299

Short RE, Bellows RA, Staigmiller RB, Berardinelli JG, Custer EE (1990) Physiological mechanisms controlling anestrus and infertility in postpartum beef cattle. J Anim Sci 68, 799-816

Till AR, Downes AM (1963) A metabolism cage for sheep. Lab Prac 12, 1006-1009

Ward KA, Franklin IR, Murray JD, Nancarrow CD, Raphael KA, Rigby NW, Byrne CR, Wilson BW, Hunt CL (1986) The direct transfer of DNA by embryo microinjection. Proc 3rd World Congr Genet Appl Livest Prod 12, 6-21

Wheeler AG (1973) Seasonal variation in oestrus and ovarian activity of Finnish Landrace, Tasmanian Merino and Scottish Blackface ewes. PhD Thesis, University of Edinburgh, Edinburgh, UK

Yu HK, Cabalum T, Jansen CAM, Buster JE, Nathanielsz PW (1983) Androstenedione, testosterone and estradiol concentrations in fetal and maternal plasma in late pregnancy in the sheep. Endocrinology 113, 2216-2220 